\title{
Current and upcoming approaches to exploit the reversibility of epigenetic mutations in breast cancer
}

Fahimeh Falahi ${ }^{1 \dagger}$, Michel van Kruchten ${ }^{2 \dagger}$, Nadine Martinet ${ }^{3}$, Geke AP Hospers ${ }^{2}$ and Marianne G Rots ${ }^{1 *}$

\begin{abstract}
DNA methylation and histone modifications are important epigenetic modifications associated with gene (dys) regulation. The epigenetic modifications are balanced by epigenetic enzymes, so-called writers and erasers, such as DNA (de)methylases and histone (de)acetylases. Aberrant epigenetic alterations have been associated with various diseases, including breast cancer. Since aberrant epigenetic modifications are potentially reversible, they might represent targets for breast cancer therapy. Indeed, several drugs have been designed to inhibit epigenetic enzymes (epi-drugs), thereby reversing epigenetic modifications. US Food and Drug Administration approval has been obtained for some epi-drugs for hematological malignancies. However, these drugs have had very modest anti-tumor efficacy in phase I and II clinical trials in breast cancer patients as monotherapy. Therefore, current clinical trials focus on the combination of epi-drugs with other therapies to enhance or restore the sensitivity to such therapies. This approach has yielded some promising results in early phase II trials. The disadvantage of epi-drugs, however, is genome-wide effects, which may cause unwanted upregulation of, for example, pro-metastatic genes. Development of gene-targeted epigenetic modifications (epigenetic editing) in breast cancer can provide a novel approach to prevent such unwanted events. In this context, identification of crucial epigenetic modifications regulating key genes in breast cancer is of critical importance. In this review, we first describe aberrant DNA methylation and histone modifications as two important classes of epigenetic mutations in breast cancer. Then we focus on the preclinical and clinical epigenetic-based therapies currently being explored for breast cancer. Finally, we describe epigenetic editing as a promising new approach for possible applications towards more targeted breast cancer treatment.
\end{abstract}

\section{Introduction}

Cells in one organism generally contain the same genetic information but present very different gene expression profiles. Epigenetic modifications underlie cell identity by switching genes on or off during mammalian development, without altering the DNA sequence. The heritability of epigenetic modifications plays critical roles in maintaining cell-type-specific gene expression during cell divisions [1]. DNA methylation and histone modification signatures, especially those on promoter regions of genes, are well known to be associated with gene expression.

\footnotetext{
* Correspondence: m.g.rots@umcg.nl

${ }^{\dagger}$ Equal contributors

'Department of Pathology and Medical Biology, University Medical Center Groningen, University of Groningen, Groningen 9700 RB, the Netherlands Full list of author information is available at the end of the article
}

DNA methylation, the first identified epigenetic modification, is written by a family of DNA methyltransferases (DNMTs). It occurs on carbon 5 of the cytosine mostly in the context of the dinucleotide cytosine phosphate guanine; it is classically known that the DNA methylation status of promoter regions is inversely correlated with gene expression [2]. As such, DNA hypermethylation has been suggested to inhibit expression of retroposons/transposons, and DNA methylation may be involved in establishing as well as maintaining monoallelic patterns of genes (for example, imprinting and $\mathrm{X}$-chromosome inactivation) [3]. In addition, DNA methylation is thought to be a key player in prevention of chromosomal instability, translocations and gene disruption [1]. DNA methylation was thought to be irreversible until the recent discovery of enzymes that 
oxidize the methylated cytosine and convert it to hydroxymethyl cytosine, providing intermediates in the process of active DNA demethylation $[3,4]$.

In addition to DNA methylation, various post-translational histone modifications have been described to be associated with gene expression [1]. In nucleosomes, the histone octamer proteins (generally two copies each of $\mathrm{H} 2 \mathrm{~A}, \mathrm{H} 2 \mathrm{~B}$, $\mathrm{H} 3$, and $\mathrm{H} 4$ ) provide the scaffold around which $147 \mathrm{bp}$ of nuclear DNA is wrapped. Histone tails (especially the amino-terminal domains of histones) undergo extensive post-translational histone modifications (for example, acetylation, methylation, ubiquitination, phosphorylation) on some residues, especially lysine and arginine [1] (Figure 1).

Histone modifications as well as DNA methylation are reversible. A very dynamic form of post-translational histone modification is histone acetylation, which mainly occurs on lysine residues and involves histone acetyltransferases (HATs) and histone deacetylases (HDACs) (Figure 1). There are four classes of HDACs with 18 members, HDACs 1 to 11 and Sirtuins 1 to 7 . Acetylation of histones reduces their negative charge, thereby, according to early in vitro studies, reducing the strength of the histone-DNA interaction and making DNA accessible to transcription factors. Although it is still believed to be involved in regulation of gene transcription, acetylation of histone tails would not be sufficient by itself to regulate gene transcription in vivo and in the chromatin context. The effect of histone acetylation on gene regulation is dependent on various factors, including, but not limited to, the position of acetylation [5].

Various epigenetic enzymes are continuously acting to maintain the balance of epigenetic modifications by inducing ('writers') or removing ('erasers') epigenetic modifications. Other epigenetic players bind to epigenetic modifications ('readers') and recruit further re-enforcing complexes (Figure 1). Malfunctioning of these enzymes results in aberrant epigenetic modifications (epigenetic mutations). Since epigenetic enzymes interact with, recruit or suppress each other, while also epigenetic modifications recruit epigenetic enzymes [6], malfunctioning of any epigenetic enzyme can be sufficient to severely affect the epigenome and disrupt the normal state of the cell. The function of epigenetic enzymes is thus vital in maintaining the normal state of cells.

In cancer, numerous epigenetic enzymes are frequently mutated and/or dysregulated, resulting in altered epigenetic modifications [1,2,7-10]. The dysregulated epigenetic

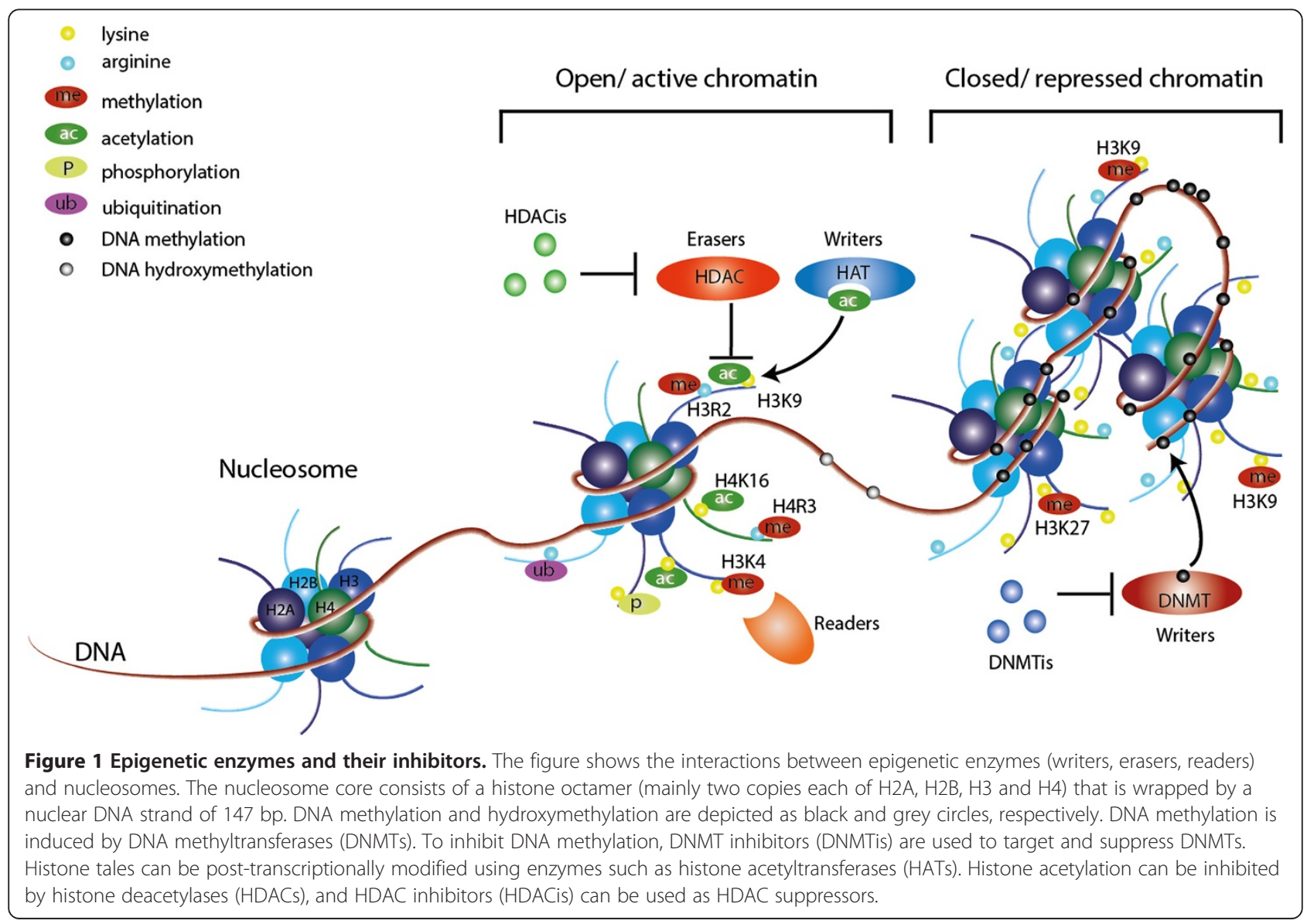


enzymes in cancer are potential targets of several classes of inhibitors, including DNMT inhibitors (DNMTis), HDAC inhibitors (HDACis), and the recently developed inhibitors of histone methyltransferases and HATs. Inhibitors of epigenetic enzymes used in (pre)-clinical treatments are so-called epi-drugs.

\section{Epigenetics and breast cancer}

Extensive studies on epigenome changes in breast cancer have been undertaken to understand the role of epigenetics in breast cancer and to develop novel epigenetic therapies. Such studies have demonstrated the association of aberrant DNA hypomethylation not only with cancer in general, but also with breast cancer [11]. In addition to global blocks of DNA hypomethylation, which underlies chromosomal instability and disturbed gene expression patterns, hypermethylation of promoter regions of, for example, tumor suppressor genes is found in breast cancer [12]. Decreased levels of DNA hydroxymethylation are also observed in breast tumors versus normal breast tissue [13].

Besides the hypermethylated tumor suppressor genes, genes involved in DNA repair, apoptosis, metabolism, cell cycle regulation, cell adherence, metastasis, cellular homeostasis, and cell growth and genes encoding several epigenetic enzymes are frequently hypermethylated in breast cancer $[2,12]$. Aberrant DNA hypermethylation of some key genes in breast cancer might be useful as prognostic or diagnostic markers. For instance, aberrant hypermethylation of genes encoding estrogen receptor (ER)- $\alpha$ and progesterone receptor (PR) is correlated with silencing of these genes and with development of ERand PR-negative breast cancer. Indeed, some hypermethylated genes, such as RASSF1A, are considered as potential diagnostic markers of breast cancer [2]. Also, aberrant DNA hypermethylation of the gene PITX2 (paired like homeodomain transcription factor-2) in breast cancer was recently considered as a marker linked to tamoxifen resistance [2]. Thus, the DNA methylation status of such genes might show value as a predictive marker for therapy response.

Another common occurrence in cancer is the global reduction of monoacetylated lysine 16 of histone $\mathrm{H} 4$ (H4K16) [13]. The loss or low levels of H4K16 acetylation was suggested as an early event in breast cancer $[7,14]$ and is associated with altered levels of HDACs [15]. Moreover, mutated HATs have been reported in breast cancer [1]. Altered histone methylation patterns [16] as well as mutated histone methyltransferases are also observed in breast cancer [1].

Altogether, maintenance of the balance of epigenetic modifications by epigenetic enzymes is essential for the regulation of gene expression and the maintenance of the normal status of cells. Clearly, malfunctioning of epigenetic enzymes and the subsequent aberrant epigenetic modifications are involved in development and progression of different cancer types, including breast cancer. Treatments to reverse the aberrant epigenetic modifications are currently under intensive preclinical and clinical investigations and are discussed below.

\section{Preclinical studies on epigenetic therapy for breast cancer}

The reversible nature of epigenetic modifications makes epigenetic mutations attractive targets for epigenetic therapy of cancer. Currently, intensive research is focused on inhibiting epigenetic enzymes such as DNMTs and HDACs. Although aberrant histone methylation modifications occur in breast cancer, to the best of our knowledge there is no report describing the effects of any histone methyltransferase inhibitors on breast cancer. DNMTis and HDACis have been tested as therapeutic interventions against several tumor types, including breast cancer. Here, we discuss the different DNMTis and HDACis and their efficacy in preclinical breast cancer studies.

\section{DNA methyltransferase inhibitors}

DNMTis are used to prevent DNA re-methylation after cell division and can be classified as nucleoside analogues and non-nucleoside analogues. Azacitidine (5azaC, Vidaza, Celgene Corp., Summit, NJ, USA) and decitabine (5azadC, Dacogen ${ }^{\oplus}$, SuperGen, Inc., Dublin, CA, USA) are two well-known examples of nucleoside analogues [17]. Both are incorporated into the DNA during replication and, by forming covalent bonds with DNMTs, they trap them and block their functions [17].

Azacitidine is considered a global DNMTi and can be incorporated into both DNA and RNA. For example, upon treatment of breast cancer cells with azacitidine, DNA re-methylation was inhibited for 23 out of 26 tested hypermethylated genes in breast cancer. Further analysis of five selected genes demonstrated their reexpression [18].

Animal studies further validated the potential therapeutic implications of such observations. Assessment of several therapeutic doses of azacitidine showed association of azacitidine with tumor size reduction of xenografts derived from breast cancer cells [19]. In this study, treatment of the immunodeficient mice with $0.5 \mathrm{mg} / \mathrm{kg}$ azacitidine for 5 days a week was correlated with growth inhibition of patient-derived tumors that were engrafted orthotopically into these mice [19].

Decitabine treatment also prevents DNA re-methylation and re-activates silenced genes [19]. For example, it was able to induce tumor necrosis factor related apoptosisinducing ligand (TRAIL) in triple-negative breast cancer cells [20], which can explain how this DNMTi makes 
breast cancer cells sensitive to chemotherapeutic agents [21]. Decitabine treatment of animals with orthotopically implanted breast cancer cells resulted in reduced tumor volume [22]. Similarly, breast cancer cells pre-treated with decitabine showed diminished tumor growth upon xenografting [19].

Importantly, demethylation and re-expression of genes involved in endocrine therapy response, such as ESR1 (encoding ER- $\alpha$ ), can be exploited to overcome endocrine therapy resistance in ER-negative breast cancer [2]. Such strategies open new possibilities for otherwise difficult-to-treat breast cancers.

Non-nucleoside DNMTis include several classes of natural compounds, such as the polyphenols [17]. Epigallocatechin-3-gallate, a major catechin found in green tea extract, was found to induce apoptosis in breast cancer via inhibiting expression of genes such as VEGF (vascular endothelial growth factor) [23] and it was shown to induce re-expression of ESR1 in breast cancer cells [24].

So regardless of the type of agent, inhibition of DNMTs results in re-expression of tumor suppressor genes associated with inhibition of growth of cancer cells.

\section{Histone deacetylase inhibitors}

HDACis chelate the zinc co-enzyme factor, thereby blocking HDACs catalytic activity. HDACis are divided into four groups: short chain fatty acids (for example, sodium butyrate, valproic acid), hydroxamic acids (for example, trichostatin A, vorinostat, panobinostat), cyclic tetrapeptides (for example, depsipetide, romidepsin (isostax)), and benzamides (for example, entinostat, tacedinaline) [20].

HDACis as monotreatment in vitro and in vivo have several anticancer effects on breast cancer, including growth arrest, the induction of apoptosis, and cellular differentiation [20,25-27].

In addition to their efficacy as preclinical monotherapy in breast cancer cells, HDACis enhance sensitivity to radiotherapy [20] and cytotoxic agents [28]. For example, the combination of vorinostat and TRAIL resulted in significant growth inhibition when compared with either treatment alone in mice bearing TRAILresistant tumor xenografts [28]. Various HDACis, including valproic acid, trichostatin $\mathrm{A}$, and entinostat, have been shown to play a role in overcoming resistance to therapies. In this respect, HDACis can be exploited for overcoming resistance to HER2-targeted therapies [29]. Also, HDACis are well accepted for their anticancer activities through promoting re-expression of silenced genes such as ESR1 in vitro and in vivo [30,31]. Moreover, re-expression of ESR1 re-sensitized breast cancer cells to the ER-targeted therapy tamoxifen in vitro $[24,32]$. Paradoxically, HDACis have non-selective effects on non-histone proteins, which might cause opposite effects. For example, in ER-positive breast cancer cells, ER- $\alpha$ expression decreased upon treatment with vorinostat. This effect can be due to increased acetylation levels of heat shock proteins, which are known to stabilize the ER- $\alpha$ protein and inhibit its degradation [33]. Despite these opposite effects, however, the combination of HDACis and endocrine therapy acted synergistically in ER-positive models [34].

\section{FDA approved epi-drugs in oncology}

Azacitidine and decitabine are both approved by the United States Food and Drug Administration (FDA) for the treatment of myelodysplastic syndrome. Azacitidine is administered by subcutaneous or intravenous injections once daily for 7 days followed by 21 days without treatment. Decitabine is given intravenously thrice daily for 3 consecutive days followed by 4 days without treatment. In the setting of myelodysplastic syndrome, both treatments provide an objective response (complete + partial response) of 16 to $17 \%$ compared with no response in untreated controls. Both regimens show comparable toxicity profiles, with myelosuppression, gastrointestinal complaints and constitutional symptoms the most common side effects [35].

Vorinostat and romidepsin are FDA-approved HDACis for the treatment of cutaneous T-cell lymphoma; in addition, romidepsin is approved for the treatment of peripheral T-cell lymphoma [36]. Vorinostat $400 \mathrm{mg}$ orally once daily induced objective responses in approximately $30 \%$ of patients [37]. The most common adverse events include myelosuppression, gastrointestinal side effects and fatigue [37]. Administration of romidepsin as a 4-hour infusion on days 1,8 , and 15 of a 28-day cycle with a starting dose of $14 \mathrm{mg} / \mathrm{m}^{2}$ resulted in an objective response in $34 \%$ of patients with cutaneous T-cell lymphoma $[38,39]$ and in $38 \%$ of patients with peripheral T-cell lymphoma [40]. Side-effects are comparable to those of vorinostat.

\section{Efficacy of epi-drugs in breast cancer patients}

The efficacy of DNMTis and HDACis in breast cancer was evaluated in 21 phase I and II studies that enrolled 303 patients with breast cancer (Table 1). In 11 of these studies ( $n=87$ patients) epi-drugs were administered to the patient either as monotherapy or in combination with another epi-drug. Most of these studies were phase I studies (64\%) in advanced solid tumors and were, therefore, not primarily aimed to evaluate anti-tumor efficacy, including only few patients who were, in general, heavily pre-treated. Nevertheless, epi-drugs in breast cancer have consistently shown very limited anti-tumor efficacy on their own. Of 87 patients receiving epi-drugs as monotherapy, objective responses were observed in only 9 (10\%). The limited efficacy of epi-drugs at the maximum tolerated dose suggests that they are not well 
Table 1 Efficacy of epi-drug monotherapy and combination therapies in breast cancer patients

\begin{tabular}{|c|c|c|c|c|c|}
\hline Epi-drug & Phase & Co-treatment & Number of patients & OR/CBR & Reference \\
\hline \multicolumn{6}{|l|}{ Monotherapy } \\
\hline Azacitidine & I & None & 11 & $7 / N A$ & {$[42]$} \\
\hline Azacitidine plus valproic acid & 1 & & 4 & $0 / 0$ & [43] \\
\hline Decitabine & I & & 4 & O/NA & [41] \\
\hline \multirow[t]{2}{*}{ Fazarabine } & । & & 3 & $1 / 1^{a}$ & [44] \\
\hline & $\|$ & & 14 & $0 / 0$ & {$[45]$} \\
\hline Phenylbutyrate & 1 & & 5 & O/NA & {$[46]$} \\
\hline \multirow[t]{4}{*}{ Vorinostat } & $\|$ & & 14 & $0 / 3$ & [47] \\
\hline & $\|$ & & 3 & $0 / 0$ & {$[48]$} \\
\hline & $\|$ & & 26 & $1 / 1$ & [49] \\
\hline & Biomarker study & & - & NA & {$[50]$} \\
\hline Vorinostat plus Decitabine & 1 & & 3 & $0 / 0$ & [51] \\
\hline Total & & & 87 & $9(10 \%) / N A$ & \\
\hline \multicolumn{6}{|l|}{ Combination therapies } \\
\hline Azacitidine & 1 & Erlotinib & 1 & $0 / 1$ & {$[52]$} \\
\hline Decitabine & 1 & Carboplatin & 5 & O/NA & [53] \\
\hline Entinostat & $\|$ & Exemestane & $64^{b}$ & $4 / 18$ & [54] \\
\hline \multirow[t]{2}{*}{ Valproic acid } & $\|$ & 5-Fluoruracil, epirubicin and cyclophosphamide & 15 & 9/NA & {$[55]$} \\
\hline & I & Followed by epirubicine & 10 & $3 / 7$ & {$[56]$} \\
\hline \multirow[t]{2}{*}{ Valproic acid plus hydralazine } & $\|$ & Standard chemotherapy & 3 & $0 / 0$ & {$[57]$} \\
\hline & 1 & Doxorubicin plus cyclophosphamide & 16 & $13 / \mathrm{NA}$ & {$[58]$} \\
\hline \multirow[t]{3}{*}{ Vorinostat } & I & Doxorubicin & 5 & $1 / 1$ & [59] \\
\hline & $|-| \mid$ & Paclitaxel plus bevacizumab & 54 & $26 / 42$ & [60] \\
\hline & $\|$ & Tamoxifen & 43 & $8 / 17$ & {$[35]$} \\
\hline Total & & & 216 & $64(30 \%) / N A$ & \\
\hline
\end{tabular}

${ }^{a}$ Clinical response. ${ }^{b}$ An additional 67 patients were randomized to exemestane plus placebo. CBR, objective response + stable disease $>6$ months); OR, objective response (partial + complete remission); NA, not available.

suited as monotherapy in breast cancer. However, biological efficacy at the epigenetic level was observed; for instance, pre- and post-treatment tumor biopsies showed significant reduction in tumor DNA methylation after decitabine monotherapy [41].

Given that epi-drugs can alter the expression of therapeutic targets, this led to the hypothesis that they should especially be administered as a (re-)sensitizer for drugs to which intrinsic or acquired resistance exists. This novel approach has rendered promising results in other tumor types in clinical trials. Decitabine was shown to allow the re-expression of the copper transporter CTR1, which plays a role in cellular platinum-uptake, in patients with solid tumors and lymphoma [41], and restore sensitivity to platinum-based chemotherapy in ovarian cancer $[61,62]$. A combination of epi-drugs with cytotoxic or targeted therapies, such as ER-targeted therapy, was evaluated in 10 phase I/II studies in 216 breast cancer patients. The largest study so far is a phase II study in which 130 metastatic breast cancer patients were randomized to exemestane plus placebo $(n=66)$ or exemestane plus entinostat $(n=64)$ [54]. These patients had earlier progressed on a nonsteroidal aromatase inhibitor. The combination of exemestane plus entinostat significantly improved progression-free survival (4.3 versus 2.3 months) and overall survival (28.1 versus 19.8 months) [54]. In another phase II study in 43 patients with metastatic breast cancer who progressed on at least one prior line of endocrine therapy, vorinostat $200 \mathrm{mg}$ twice daily was combined with tamoxifen [35]. In this study, the objective response rate was $19 \%$ and the clinical benefit rate (objective response or stable disease $>6$ months) was $40 \%$. Baseline high HDAC2 levels correlated with response, which may prove valuable as a predictive biomarker to select patients for treatment with HDACis. Finally, in a phase I/II study in 54 patients with metastatic breast cancer, vorinostat 200 to $300 \mathrm{mg}$ twice daily on days 1 to 3,8 to 10 , and 15 to 17 was added to paclitaxel plus bevacizumab [60]. This combination resulted in a $49 \%$ objective response rate (partial + complete remission) and 78\% clinical 
benefit rate (objective response + stable disease $>6$ months) Serial biopsies, available from seven patients, showed an increase in acetylation of heat shock protein 90 and $\alpha$-tubulin.

Although there is preclinical evidence for enhanced efficacy of HER2-targeted therapies when combined with epi-drugs, results from clinical studies are awaited.

In conclusion, epi-drugs have limited anti-tumor efficacy in breast cancer patients at the maximum tolerated dose when administered as monotherapy, but can be administered safely. However, expected epigenetic changes, such as decreased tumor DNA methylation [41], increased histone acetylation [60], and upregulation of gene expression [58], are observed after their administration in clinical breast cancer studies. Current studies suggest a potential role for epi-drugs in combination with chemotherapeutics and targeted therapies to enhance or restore the sensitivity to these drugs.

\section{Current breast cancer trials evaluating epi-drugs}

Ongoing trials increasingly apply epi-drugs to specific subgroups rather than to the general breast cancer population. Much work is performed on (re-)sensitization of endocrine-resistant tumors to endocrine therapy. In patients with triple-negative or hormone-refractory metastatic breast cancer, azacitidine is combined with entinostat; although the response rate is the primary endpoint in this study, the effects on ER and PR expression will be evaluated as secondary endpoints (NCT01349959). A novel, non-invasive way to measure ER expression is by molecular imaging using positron emission tomography (PET) and ${ }^{18}$ F-fluoroestradiol (FES) as a tracer [63]. This tool facilitates the assessment of ER expression during treatment. In a study, hormone-refractory patients are being treated with daily vorinostat for 2 weeks, followed by a treatment with an aromatase inhibitor for 6 weeks (NCT01153672). Cycles are repeated every 8 weeks until progression. As a secondary endpoint, changes in ER expression will be measured using serial FES-PET imaging. Panobinostat and decitabine are also being evaluated to sensitize triple-negative breast cancer patients to endocrine therapy in phase I/II studies (NCT01194908, NCT01105312).

The use of DNMTis and HDACis as chemo-sensitizers is also being evaluated in various breast cancer trials (for example, NCT00748553, NCT00368875). Among the evaluated combinations are azacitidine with Nab-paclitaxel (Abraxane ${ }^{\oplus}$, Abraxis Bioscience, Los Angeles, CA, USA), valproic acid with $\mathrm{FEC}$, and vorinostat with paclitaxel plus bevacizumab. Finally, sensitization to HER2-targeted therapy will be evaluated in a limited number of studies. One phase I/II study evaluated $200 \mathrm{mg}$ vorinostat twice daily on days 1 to 14 combined with trastuzumab $6 \mathrm{mg} / \mathrm{kg}$ once every 3 weeks. This study enrolled 16 patients and was terminated due to low response rate (NCT00258349).
Another study will evaluate the safety and efficacy of vorinostat combined with the tyrosine kinase inhibitor lapatinib (NCT01118975). Also, several studies using panobinostat to sensitize breast cancer to trastuzumab (NCT00788931, NCT00567879), and lapatinib (NCT00632489) have recently been completed and results are awaited. All trials were phase I or II. An overview of ongoing trials with DNMTis and/or HDACis in breast cancer is provided in Table 2.

\section{Epigenetic editing}

Despite the above-described promises, epi-drugs affect genes in a genome-wide manner, as well as inhibit writers and erasers, which generally also modify non-chromatin proteins. Such aspecific mechanisms of action result in unwanted effects, including upregulation of prometastatic genes [64] or of genes encoding drug resistance-associated proteins [65]. To fully exploit the reversible nature of epigenetic mutations while avoiding unwanted effects, epigenetic therapy can be improved using gene targeting approaches: by fusing a writer or eraser of a particular epigenetic mark to a self-engineered DNA binding domain, rewriting of the epigenetic signature of a selected target gene (epigenetic editing) is achieved [6]. To obtain sequence-targeted DNA binding, zinc finger proteins (ZFPs), triplex forming oligos, transcription activator-like effectors (TALEs), or catalytically inactive Cas proteins of the clustered regularly interspaced short palindromic repeats system $[66,67]$ can be fused to the catalytic domains of epigenetic enzymes (epigenetic effector domains) $[6,68]$ or to epi-drugs [69]. The epigenetic effector domain of an epigenetic editing tool will subsequently overwrite epigenetic modifications at the targeted gene. Because of cellular epigenetic maintenance processes, edited epigenetic modifications (or sets thereof) might remain on the DNA or histone tails, even after removal of the epigenetic editing tool. Moreover, written epigenetic modifications can spread along the target gene $[70,71]$ due to subsequent recruitment of endogenous epigenetic enzymes [72,73]. Interestingly, adequately rewritten epigenetic modifications might be inherited by subsequent cell generations [74], thereby allowing permanent changes to genome functioning without changing genomic sequences. Altogether, epigenetic editing provides a promising novel avenue to interfere with gene expression levels in a persistent manner.

As epigenetic editing targets a gene directly at the DNA level, this targeting of generally two copies of DNA offers advantages over targeting multiple copies of or different isoforms of proteins or RNA. Moreover, since RNA and protein molecules are constantly being expressed, their sustained inhibition requires continuous administration of inhibitors or potentially harmful integration of the (RNA interference) transgene expression cassette into the host genome. Epigenetic editing allows 
Table 2 Overview of current clinical trials evaluating DNMT-inhibitors and HDAC-inhibitors in breast cancer

\begin{tabular}{|c|c|c|c|c|c|c|c|}
\hline Drug & Condition & Co-treatment & Primary outcome measure & $N$ & Phase & Status & $\begin{array}{l}\mathrm{NCT} \\
\text { number }\end{array}$ \\
\hline \multicolumn{8}{|l|}{$\begin{array}{l}\text { DNMT } \\
\text { inhibitor }\end{array}$} \\
\hline \multirow[t]{2}{*}{ Azacitidine } & Advanced BC & Entinostat $^{\mathrm{a}}$ & Objective response rate & 60 & $\|$ & $\mathrm{R}$ & 01349959 \\
\hline & Advanced/metastatic BC & Nab-paclitaxel & & 45 & $|/| \mid$ & $\mathrm{R}$ & 00748553 \\
\hline Decitabine & $\begin{array}{l}\text { Advanced/ } \\
\text { metastatic TNBC }\end{array}$ & 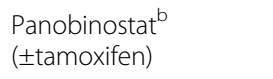 & $\begin{array}{l}\text { The maximum tolerated dose of } \\
\text { decitabine and panobinostat }\end{array}$ & 60 & $|/| \mid$ & $\mathrm{R}$ & 01194908 \\
\hline FdCyd & Solid tumors, including BC & Tetrahydrouridine & To determine the safety of FdCyd & 20 & । & $\mathrm{R}$ & 01479348 \\
\hline FdCyd & Solid tumors, including BC & Tetrahydrouridine & $\begin{array}{l}\text { To determine PFS and/or response rate } \\
\text { of FdCyd plus tetrahydrouridine }\end{array}$ & 185 & । & $\mathrm{R}$ & 00978250 \\
\hline \multirow[t]{3}{*}{ EGCG } & Newly diagnosed BC & - & $\begin{array}{l}\text { To determine whether EGCG can affect } \\
\text { proliferation rate and induce apoptosis }\end{array}$ & 20 & $\|$ & $\mathrm{R}$ & 00949923 \\
\hline & Newly diagnosed BC & - & $\begin{array}{l}\text { To evaluate the effects of EGCG on various } \\
\text { biomarkers }\end{array}$ & 32 & $\|$ & A & 00676793 \\
\hline & Stage I-III BC & - & $\begin{array}{l}\text { To determine the safety and maximum } \\
\text { tolerated dose of EGCG }\end{array}$ & 40 & । & A & 00516243 \\
\hline \multicolumn{8}{|l|}{$\begin{array}{l}\text { HDAC } \\
\text { inhibitor }\end{array}$} \\
\hline \multirow[t]{11}{*}{ Vorinostat } & $B C$ & Lapatinib & Clinical benefit rate & 47 & $|/| \mid$ & $\mathrm{R}$ & 01118975 \\
\hline & Recurrent/metastatic BC & - & To evaluate the safety of vorinostat & 49 & $|/| \mid$ & A & 00416130 \\
\hline & Advanced BC & Capecitabine & $\begin{array}{l}\text { The maximum tolerated dose, safety, } \\
\text { and efficacy of vorinostat plus capecitabine }\end{array}$ & 47 & $\|$ & U & 00719875 \\
\hline & $\begin{array}{l}\text { Local recurrent/metastatic } \\
\text { BC }\end{array}$ & $\begin{array}{l}\text { Paclitaxel/ } \\
\text { bevacizumab }\end{array}$ & $\begin{array}{l}\text { The maximum tolerated dose, and objective } \\
\text { response rate of vorinostat in combination } \\
\text { with paclitaxel/bevacizumab }\end{array}$ & 58 & $|/| \mid$ & U & 00368875 \\
\hline & Metastatic BC & Ixabepilone & Dose limiting toxicity & 56 & । & A & 01084057 \\
\hline & Hormone-refractory BC & Aromatase inhibitor & Clinical benefit rate & 14 & $\|$ & $\mathrm{R}$ & 01720602 \\
\hline & Locally advanced BC & Paclitaxel/trastuzumab & $\begin{array}{l}\text { To determine the recommended } \\
\text { phase II dose }\end{array}$ & 54 & $|/| \mid$ & U & 00574587 \\
\hline & Hormone-refractory BC & Aromatase inhibitor & Clinical benefit rate & 20 & $\|$ & $\mathrm{R}$ & 01153672 \\
\hline & Newly diagnosed BC & $\begin{array}{l}\text { Nab-paclitaxel/ } \\
\text { carboplatin }\end{array}$ & Pathologic complete response rate & 74 & $\|$ & A & 00616967 \\
\hline & $\begin{array}{l}\text { HIV + with solid tumor, } \\
\text { including } B C\end{array}$ & Paclitaxel/carboplatin & Maximum tolerated dose & 66 & । & $\mathrm{R}$ & 01249443 \\
\hline & $\begin{array}{l}\text { Brain metastases, } \\
\text { including from BC }\end{array}$ & $\begin{array}{l}\text { Paclitaxel/carboplatin } \\
\text { plus radiotherapy }\end{array}$ & Maximum tolerated dose & 24 & I & A & 00838929 \\
\hline \multirow[t]{4}{*}{ Entinostat } & $\begin{array}{l}\text { Locally recurrent/metastatic } \\
\mathrm{ER}+\mathrm{BC} \text {, or } \mathrm{NSCLC}\end{array}$ & \pm Exemestane & $\begin{array}{l}\text { Pharmacokinetics of entinostat in } \\
\text { fasted and fed subjects }\end{array}$ & 28 & I & $\mathrm{R}$ & 01594398 \\
\hline & Newly diagnosed TNBC & Anastrozole & $\begin{array}{l}\text { Safety, tolerability and recommended } \\
\text { phase II dose (phase I cohort); change in } \\
\text { proliferation, ER/PR expression (phase II cohort) }\end{array}$ & 41 & $|/| \mid$ & $\mathrm{R}$ & 01234532 \\
\hline & $\begin{array}{l}\text { HER2-positive } \\
\text { metastatic BC }\end{array}$ & Lapatinib & $\begin{array}{l}\text { Recommended phase II dose (phase I cohort); } \\
\text { objective response rate (phase || cohort) }\end{array}$ & 70 & $|/| \mid$ & $\mathrm{R}$ & 01434303 \\
\hline & Advanced BC & Azacitidine $^{a}$ & Objective response rate & 60 & $\|$ & $\mathrm{R}$ & 01349959 \\
\hline \multirow[t]{3}{*}{ Panobinostat } & Metastatic TNBC & Letrozole & $\begin{array}{l}\text { Maximum tolerated dose, adverse events } \\
\text { (phase I cohort); response rate (phase II cohort) }\end{array}$ & 48 & $|/| \mid$ & $\mathrm{R}$ & 01105312 \\
\hline & Advanced/metastatic TNBC & $\begin{array}{l}\text { Decitabine } \\
\text { ( } \pm \text { tamoxifen })\end{array}$ & $\begin{array}{l}\text { The maximum tolerated dose of decitabine } \\
\text { and panobinostat }\end{array}$ & 60 & $|/| \mid$ & $\mathrm{R}$ & 01194908 \\
\hline & $\begin{array}{l}\text { HER2-negative locally } \\
\text { recurrent/metastatic BC }\end{array}$ & - & Objective response rate & 118 & $\|$ & A & 00777049 \\
\hline VPA & $\begin{array}{l}\text { Newly diagnosed locally } \\
\text { advanced/metastatic BC }\end{array}$ & FEC & Pathologic response rate & 55 & $\|$ & $\mathrm{R}$ & 01010854 \\
\hline
\end{tabular}


Table 2 Overview of current clinical trials evaluating DNMT-inhibitors and HDAC-inhibitors in breast cancer (Continued)

\begin{tabular}{|c|c|c|c|c|c|c|c|}
\hline & Newly diagnosed BC & - & $\begin{array}{l}\text { To determine whether VPA levels correlate } \\
\text { with leukocyte and tumor histone acetylation }\end{array}$ & 33 & NA & $R$ & 01007695 \\
\hline Depsipeptide & $\begin{array}{l}\text { Solid or hematologic } \\
\text { malignancy, including BC }\end{array}$ & - & $\begin{array}{l}\text { Safety, tolerability, maximum tolerated dose } \\
\text { and pharmacokinetics }\end{array}$ & 132 & I & $\mathrm{R}$ & 01638533 \\
\hline
\end{tabular}

$N=$ estimated enrolment. Status: $\mathrm{A}=$ active, not recruiting; $\mathrm{C}=$ completed; $\mathrm{R}=$ recruiting; $\mathrm{U}=$ unknown. ${ }^{\mathrm{a}, \mathrm{b}}$ Cross-referenced within table. $\mathrm{BC}$, breast cancer; $\mathrm{DNMT}$, DNA methyltransferase; EGCG, epigallocatechin-3-gallate; ER, estrogen receptor; HDAC, histone deacetylase; NA, not applicable; NSCLC, non small-cell lung cancer; PFS, progression-free survival; PR, progesterone receptor; TNBC, triple-negative breast cancer; VPA, valproic acid.

a hit-and-run approach to directly silence the source of the RNA production. Alternatively, for upregulation of a gene's expression level, epigenetic editing tools can be engineered to remove epigenetic repressive marks and/or induce activating marks at selected loci. Such overwriting of repressive signatures will allow transcription of alternative isoforms to take place, in their natural ratios. For example, for upregulation of tumor suppressor genes that are frequently silenced by epigenetic mutations, activating the expression from their endogenous DNA loci better mimics nature than administration of ectopic cDNA expression constructs, which result in overexpression of only one isoform of a gene.

Proofs of concept for locus-specific epigenetic overwriting have been described for numerous epigenetic effector domains [6]. To date, 10 papers describe epigenetic editing on endogenous genes. Using engineered ZFPs, we showed that targeted DNA methylation is instructive in gene expression downregulation (for example, of MASPIN [75], VEGF-A [76], and EpCAM [77]). Interestingly, targeted DNA demethylation could be induced, which was effective in upregulating the expression of the targeted gene ICAM-1 [78]. We also demonstrated that writing the repressive histone methylation modification H3K9me2 on the Her2/neu gene induced Her2/neu protein downregulation, which in turn inhibited cancer cell growth [79]. Our findings for an overexpressed oncogene validated results of an earlier report on downregulation of VEGF-A [70]. Moreover, targeted DNA methylation of the SOX2 promoter prevented growth of breast cancer cells, also upon removal of the epigenetic writer [75]. Others recently joined the field and demonstrated the power of epigenetic editing as a unique research tool in addressing epigenetic control of gene expression regulation $[80,81]$. Interestingly, active DNA demethylation has also been demonstrated using engineered TALE-TET2 fusions [82] or by fusing a DNA repair enzyme to engineered ZFPs [83]. As targeting of genes has recently become widely feasible [84], epigenetic editing opens new avenues towards 'the druggable genome', and since multiplex gene targeting is currently feasible, cancer therapy approaches might also benefit from such progress.

\section{Conclusion}

Epigenetic mutations, including aberrant DNA methylation and histone modifications, are associated with breast cancer development and therapy resistance. Aberrant DNA methylation and histone acetylation can be reversed by DNMTis and HDACis. Several DNMTis and HDACis are FDA approved, albeit not so far for the treatment of patients with breast cancer. These drugs can induce apoptosis, alter gene expression, and reverse therapy resistance in preclinical models. In clinical studies, DNMTis and HDACis have shown very modest antitumor activity as monotherapy, although effects on gene expression can be observed. Current clinical trials, therefore, mainly focus on the combination of these drugs with chemotherapeutics and targeted therapies. Despite their promise, a disadvantage of DNMTis and HDACis is their genome-wide function and non-chromatin effects. Epigenetic editing of a single gene results in gene expression modulation, and thereby fully exploits the reversibility of epigenetic modifications as therapeutic targets while reducing off-target effects. Epigenetic editing and other targeted approaches thus provide alternatives to current epigenetic therapies for breast cancer.

\section{Abbreviation \\ DNMT: DNA methyltransferase; DNMTi: DNA methyltransferase inhibitor; ER: Estrogen receptor; FDA: Food and Drug Administration; FES: ${ }^{18} \mathrm{~F}-$ fluoroestradiol; H: Histone; HAT: Histone acetyltransferase; HDAC: Histone deacetylase; HDACi: Histone deacetylase inhibitor; PET: Positron emission tomography; PR: Progesterone receptor; TALE: Transcription activator-like effector; TRAIL: Tumor necrosis factor related apoptosis-inducing ligand; ZFP: Zinc finger protein.}

Competing interests

The authors declare that they have no competing interests.

\section{Acknowledgements}

This work was supported by UMCG-601005 to FF, the Dutch Cancer Society (grant RUG2009-4529) to MvK and GAPH, National scientific research organization (NWONIDI/91786373) to MGR, and EU COST TD0905 to MGR and NM.

\section{Author details}

${ }^{1}$ Department of Pathology and Medical Biology, University Medical Center Groningen, University of Groningen, Groningen 9700 RB, the Netherlands. 2Department of Medical Oncology, University Medical Center Groningen, University of Groningen, Groningen 9700 RB, the Netherlands. ${ }^{3}$ Institute of Chemistry, UMR CNRS 7272 and University of Nice Sophia Antipolis, Nice, Cedex 2 06108, France.

Published online: 29 July 2014 


\section{References}

1. Berdasco M, Esteller M: Aberrant epigenetic landscape in cancer: how cellular identity goes awry. Dev Cell 2010, 19:698-711.

2. Stefansson OA, Esteller M: Epigenetic modifications in breast cancer and their role in personalized medicine. Am J Pathol 2013, 183:1052-1063.

3. Law JA, Jacobsen SE: Establishing, maintaining and modifying DNA methylation patterns in plants and animals. Nat Rev Genet 2010, 11:204-220.

4. Tahiliani M, Koh KP, Shen Y, Pastor WA, Bandukwala H, Brudno Y, Agarwal S, lyer LM, Liu DR, Aravind L, Rao A: Conversion of 5-methylcytosine to 5-hydroxymethylcytosine in mammalian DNA by MLL partner TET1. Science 2009, 324:930-935.

5. Turner BM: The adjustable nucleosome: an epigenetic signaling module. Trends Genet 2012, 28:436-444.

6. de Groote ML, Verschure PJ, Rots MG: Epigenetic editing: targeted rewriting of epigenetic marks to modulate expression of selected target genes. Nucleic Acids Res 2012, 40:10596-10613.

7. Plass C, Pfister SM, Lindroth AM, Bogatyrova O, Claus R, Lichter P: Mutations in regulators of the epigenome and their connections to global chromatin patterns in cancer. Nat Rev Genet 2013, 14:765-780.

8. You JS, Jones PA: Cancer genetics and epigenetics: two sides of the same coin? Cancer Cell 2012, 22:9-20

9. Dawson MA, Kouzarides T, Huntly BJ: Targeting epigenetic readers in cancer. N Engl J Med 2012, 367:647-657.

10. Jones S, Li M, Parsons DW, Zhang X, Wesseling J, Kristel P, Schmidt MK Markowitz S, Yan H, Bigner D, Hruban RH, Eshleman JR, lacobuzio-Donahue CA, Goggins M, Maitra A, Malek SN, Powell S, Vogelstein B, Kinzler KW, Velculescu $V E$, Papadopoulos N: Somatic mutations in the chromatin remodeling gene ARID1A occur in several tumor types. Hum Mutat 2012, 33:100-103.

11. Portela A, Esteller M: Epigenetic modifications and human disease. Nat Biotechnol 2010, 28:1057-1068.

12. Locke WJ, Clark SJ: Epigenome remodelling in breast cancer: insights from an early in vitro model of carcinogenesis. Breast Cancer Res 2012, 14:215.

13. Haffner MC, Chaux A, Meeker AK, Esopi DM, Gerber J, Pellakuru LG, Toubaji A, Argani P, lacobuzio-Donahue C, Nelson WG, Netto GJ, De Marzo AM, Yegnasubramanian S: Global 5-hydroxymethylcytosine content is significantly reduced in tissue stem/progenitor cell compartments and in human cancers. Oncotarget 2011, 2:627-637.

14. Elsheikh SE, Green AR, Rakha EA, Powe DG, Ahmed RA, Collins HM, Soria D, Garibaldi JM, Paish CE, Ammar AA, Grainge MJ, Ball GR, Abdelghany MK, Martinez-Pomares L, Heery DM, Ellis IO: Global histone modifications in breast cancer correlate with tumor phenotypes, prognostic factors, and patient outcome. Cancer Res 2009, 69:3802-3809.

15. Linares A, Dalenc F, Balaguer P, Boulle N, Cavailles V: Manipulating protein acetylation in breast cancer: a promising approach in combination with hormonal therapies? J Biomed Biotechnol 2011, 2011:856985.

16. Varier RA, Timmers HT: Histone lysine methylation and demethylation pathways in cancer. Biochim Biophys Acta 1815, 2011:75-89.

17. Martinet $N$, Michel BY, Bertrand P, Benhida R: Small molecules DNA methyltransferases inhibitors. Med Chem Commun 2012, 3:263-273.

18. Tao Y, Liu S, Briones V, Geiman TM, Muegge K: Treatment of breast cancer cells with DNA demethylating agents leads to a release of Pol II stalling at genes with DNA-hypermethylated regions upstream of TSS. Nucleic Acids Res 2011, 39:9508-9520

19. Tsai HC, Li H, Van Neste L, Cai Y, Robert C, Rassool FV, Shin JJ, Harbom KM Beaty R, Pappou E, Harris J, Yen RW, Ahuja N, Brock MV, Stearns V, FellerKopman D, Yarmus LB, Lin YC, Welm AL, Issa JP, Minn I, Matsui W, Jang YY, Sharkis SJ, Baylin SB, Zahnow CA: Transient low doses of DNAdemethylating agents exert durable antitumor effects on hematological and epithelial tumor cells. Cancer Cell 2012, 21:430-446.

20. Cai FF, Kohler C, Zhang B, Wang MH, Chen WJ, Zhong XY: Epigenetic therapy for breast cancer. Int J Mol Sci 2011, 12:4465-4487.

21. Xu J, Zhou JY, Tainsky MA, Wu GS: Evidence that tumor necrosis factorrelated apoptosis-inducing ligand induction by 5-Aza-2'-deoxycytidine sensitizes human breast cancer cells to adriamycin. Cancer Res 2007, 67:1203-1211

22. Borges S, Doppler H, Perez EA, Andorfer CA, Sun Z, Anastasiadis PZ, Thompson EA, Geiger XJ, Storz P: Pharmacologic reversion of epigenetic silencing of the PRKD1 promoter blocks breast tumor cell invasion and metastasis. Breast Cancer Res 2013, 15:R66.
23. Braicu C, Gherman CD, Irimie A, Berindan-Neagoe I: Epigallocatechin-3Gallate (EGCG) inhibits cell proliferation and migratory behaviour of triple negative breast cancer cells. J Nanosci Nanotechnol 2013, 13:632-637.

24. Li Y, Yuan YY, Meeran SM, Tollefsbol TO: Synergistic epigenetic reactivation of estrogen receptor-a $(E R a)$ by combined green tea polyphenol and histone deacetylase inhibitor in ERa-negative breast cancer cells. Mol Cancer 2010, 9:274.

25. Cooper SJ, von Roemeling CA, Kang KH, Marlow LA, Grebe SK, Menefee ME, Tun HW, Colon-Otero G, Perez EA, Copland JA: Reexpression of tumor suppressor, sFRP1, leads to antitumor synergy of combined HDAC and methyltransferase inhibitors in chemoresistant cancers. Mol Cancer Ther 2012, 11:2105-2115.

26. Beckers T, Burkhardt C, Wieland H, Gimmnich P, Ciossek T, Maier T, Sanders $\mathrm{K}$ : Distinct pharmacological properties of second generation HDAC inhibitors with the benzamide or hydroxamate head group. Int I Cancer 2007, 121:1138-1148.

27. Kim YJ, Greer CB, Cecchini KR, Harris LN, Tuck DP, Kim TH: HDAC inhibitors induce transcriptional repression of high copy number genes in breast cancer through elongation blockade. Oncogene 2013, 32:2828-2835.

28. Shankar S, Davis R, Singh KP, Kurzrock R, Ross DD, Srivastava RK. Suberoylanilide hydroxamic acid (Zolinza/vorinostat) sensitizes TRAIL-resistant breast cancer cells orthotopically implanted in BALB/C nude mice. Mol Cancer Ther 2009, 8:1596-1605.

29. Huang X, Wang S, Lee CK, Yang X, Liu B: HDAC inhibitor SNDX-275 enhances efficacy of trastuzumab in erbB2-overexpressing breast cancer cells and exhibits potential to overcome trastuzumab resistance. Cancer Lett 2011, 307:72-79.

30. Tate CR, Rhodes LV, Segar HC, Driver JL, Pounder FN, Burow ME, Collins-Burow $\mathrm{BM}$ : Targeting triple-negative breast cancer cells with the histone deacetylase inhibitor panobinostat. Breast Cancer Res 2012, 14:R79.

31. Hervouet $\mathrm{E}$, Cartron PF, Jouvenot M, Delage-Mourroux R: Epigenetic regulation of estrogen signaling in breast cancer. Epigenetics 2013, 8:237-245.

32. Sappok A, Mahlknecht U: Ribavirin restores ESR1 gene expression and tamoxifen sensitivity in ESR1 negative breast cancer cell lines. Clin Epigenetics 2011, 3. 8-7083-3-8.

33. Fiskus W, Ren Y, Mohapatra A, Bali P, Mandawat A, Rao R, Herger B, Yang Y, Atadja P, Wu J, Bhalla K: Hydroxamic acid analogue histone deacetylase inhibitors attenuate estrogen receptor- $\alpha$ levels and transcriptional activity: a result of hyperacetylation and inhibition of chaperone function of heat shock protein 90. Clin Cancer Res 2007, 13:4882-4890.

34. Thomas S, Munster PN: Histone deacetylase inhibitor induced modulation of anti-estrogen therapy. Cancer Lett 2009, 280:184-191.

35. Munster PN, Thurn KT, Thomas S, Raha P, Lacevic M, Miller A, Melisko M, Ismail-Khan R, Rugo H, Moasser M, Minton SE: A phase II study of the histone deacetylase inhibitor vorinostat combined with tamoxifen for the treatment of patients with hormone therapy-resistant breast cancer. Br J Cancer 2011, 104:1828-1835.

36. Ververis K, Hiong A, Karagiannis TC, Licciardi PV: Histone deacetylase inhibitors (HDACls): multitargeted anticancer agents. Biologics 2013, 7:47-60.

37. Mann BS, Johnson JR, Cohen MH, Justice R, Pazdur R: FDA approval summary: vorinostat for treatment of advanced primary cutaneous T-cell lymphoma. Oncologist 2007, 12:1247-1252.

38. Whittaker SJ, Demierre MF, Kim EJ, Rook AH, Lerner A, Duvic M, Scarisbrick J, Reddy S, Robak T, Becker JC, Samtsov A, McCulloch W, Kim YH: Final results from a multicenter, international, pivotal study of romidepsin in refractory cutaneous T-cell lymphoma. J Clin Oncol 2010, 28:4485-4491.

39. Piekarz RL, Frye R, Turner M, Wright JJ, Allen SL, Kirschbaum MH, Zain J, Prince HM, Leonard JP, Geskin LJ, Reeder C, Joske D, Figg WD, Gardner ER, Steinberg SM, Jaffe ES, Stetler-Stevenson M, Lade S, Fojo AT, Bates SE: Phase II multi-institutional trial of the histone deacetylase inhibitor romidepsin as monotherapy for patients with cutaneous T-cell lymphoma. J Clin Oncol 2009, 27:5410-5417.

40. Piekarz RL, Frye R, Prince HM, Kirschbaum MH, Zain J, Allen SL, Jaffe ES, Ling A, Turner M, Peer CJ, Figg WD, Steinberg SM, Smith S, Joske D, Lewis I, Hutchins L, Craig M, Fojo AT, Wright JJ, Bates SE: Phase 2 trial of romidepsin in patients with peripheral T-cell lymphoma. Blood 2011, 117:5827-5834.

41. Stewart DJ, Issa JP, Kurzrock R, Nunez MI, Jelinek J, Hong D, Oki Y, Guo Z, Gupta S, Wistuba II: Decitabine effect on tumor global DNA methylation 
and other parameters in a phase I trial in refractory solid tumors and lymphomas. Clin Cancer Res 2009, 15:3881-3888.

42. Weiss AJ, Stambaugh JE, Mastrangelo MJ, Laucius JF, Bellet RE: Phase I study of 5-azacytidine (NSC-102816). Cancer Chemother Rep 1972, 56:413-419.

43. Braiteh F, Soriano AO, Garcia-Manero G, Hong D, Johnson MM, Silva Lde P, Yang H, Alexander S, Wolff J, Kurzrock R: Phase I study of epigenetic modulation with 5-azacytidine and valproic acid in patients with advanced cancers. Clin Cancer Res 2008, 14:6296-6301.

44. Surbone A, Ford H Jr, Kelley JA, Ben-Baruch N, Thomas RV, Fine R, Cowan $\mathrm{KH}$ : Phase I and pharmacokinetic study of arabinofuranosyl-5-azacytosine (fazarabine, NSC 281272). Cancer Res 1990, 50:1220-1225.

45. Walters RS, Theriault RL, Holmes FA, Hortobagyi GN, Esparza L: Phase II trial of fazarabine (ARA-AC, arabinosyl-5-azacytosine) in metastatic breast cancer. Invest New Drugs 1992, 10:43-44.

46. Gilbert J, Baker SD, Bowling MK, Grochow L, Figg WD, Zabelina Y, Donehower RC, Carducci MA: A phase I dose escalation and bioavailability study of oral sodium phenylbutyrate in patients with refractory solid tumor malignancies. Clin Cancer Res 2001, 7:2292-2300.

47. Luu TH, Morgan RJ, Leong L, Lim D, McNamara M, Portnow J, Frankel P, Smith DD, Doroshow JH, Wong C, Aparicio A, Gandara DR, Somlo G: A phase II trial of vorinostat (suberoylanilide hydroxamic acid) in metastatic breast cancer: a California Cancer Consortium study. Clin Cancer Res 2008, 14:7138-7142.

48. Vansteenkiste J, Van Cutsem E, Dumez H, Chen C, Ricker JL, Randolph SS, Schoffski P: Early phase II trial of oral vorinostat in relapsed or refractory breast, colorectal, or non-small cell lung cancer. Invest New Drugs 2008, 26:483-488.

49. Wong NS, Seah EZ, Wang LZ, Yeo WL, Yap HL, Chuah B, Lim YW, Ang PC, Tai BC, Lim R, Goh BC, Lee SC: Impact of UDP-gluconoryltransferase 2B17 genotype on vorinostat metabolism and clinical outcomes in Asian women with breast cancer. Pharmacogenet Genomics 2011, 21:760-768.

50. Stearns V, Jacobs LK, Fackler M, Tsangaris TN, Rudek MA, Higgins M, Lange J, Cheng Z, Slater SA, Jeter SC, Powers P, Briest S, Chao C, Yoshizawa C, Sugar E, Espinoza-Delgado I, Sukumar S, Gabrielson E, Davidson NE: Biomarker modulation following short-term vorinostat in women with newly diagnosed primary breast cancer. Clin Cancer Res 2013, 19:4008-4016.

51. Stathis A, Hotte SJ, Chen EX, Hirte HW, Oza AM, Moretto P, Webster S, Laughlin A, Stayner LA, McGill S, Wang L, Zhang WJ, Espinoza-Delgado I, Holleran $J$, Egorin MJ, Siu LL: Phase I study of decitabine in combination with vorinostat in patients with advanced solid tumors and non-Hodgkin's lymphomas. Clin Cancer Res 2011, 17:1582-1590.

52. Bauman J, Verschraegen C, Belinsky S, Muller C, Rutledge T, Fekrazad M, Ravindranathan M, Lee SJ, Jones D: A phase I study of 5-azacytidine and erlotinib in advanced solid tumor malignancies. Cancer Chemother Pharmacol 2012, 69:547-554.

53. Appleton K, Mackay HJ, Judson I, Plumb JA, McCormick C, Strathdee G, Lee C, Barrett S, Reade S, Jadayel D, Tang A, Bellenger K, Mackay L, Setanoians A, Schatzlein A, Twelves C, Kaye SB, Brown R: Phase I and pharmacodynamic trial of the DNA methyltransferase inhibitor decitabine and carboplatin in solid tumors. J Clin Oncol 2007, 25:4603-4609.

54. Yardley DA, Ismail-Khan RR, Melichar B, Lichinitser M, Munster PN, Klein PM, Cruickshank S, Miller KD, Lee MJ, Trepel JB: Randomized phase II, double-blind, placebo-controlled study of exemestane with or without entinostat in postmenopausal women with locally recurrent or metastatic estrogen receptor-positive breast cancer progressing on treatment with a nonsteroidal aromatase inhibitor. J Clin Oncol 2013, 31:2128-2135.

55. Munster P, Marchion D, Bicaku E, Lacevic M, Kim J, Centeno B, Daud A Neuger A, Minton S, Sullivan D: Clinical and biological effects of valproic acid as a histone deacetylase inhibitor on tumor and surrogate tissues: phase I/II trial of valproic acid and epirubicin/FEC. Clin Cancer Res 2009, 15:2488-2496

56. Munster P, Marchion D, Bicaku E, Schmitt M, Lee JH, DeConti R, Simon G, Fishman M, Minton S, Garrett C, Chiappori A, Lush R, Sullivan D, Daud A: Phase I trial of histone deacetylase inhibition by valproic acid followed by the topoisomerase II inhibitor epirubicin in advanced solid tumors: a clinical and translational study. J Clin Oncol 2007, 25:1979-1985.

57. Candelaria M, Gallardo-Rincon D, Arce C, Cetina L, Aguilar-Ponce IL, Arrieta O, Gonzalez-Fierro A, Chavez-Blanco A, de la Cruz-Hernandez E, Camargo MF, Trejo-Becerril C, Perez-Cardenas E, Perez-Plasencia C, Taja-Chayeb L, Wegman-Ostrosky T, Revilla-Vazquez A, Duenas-Gonzalez A: A phase II study of epigenetic therapy with hydralazine and magnesium valproate to overcome chemotherapy resistance in refractory solid tumors. Ann Oncol 2007, 18:1529-1538.

58. Arce C, Perez-Plasencia C, Gonzalez-Fierro A, de la Cruz-Hernandez E, Revilla-Vazquez A, Chavez-Blanco A, Trejo-Becerril C, Perez-Cardenas E, Taja-Chayeb L, Bargallo E, Villarreal P, Ramirez T, Vela T, Candelaria M, Camargo MF, Robles E, Duenas-Gonzalez A: A proof-of-principle study of epigenetic therapy added to neoadjuvant doxorubicin cyclophosphamide for locally advanced breast cancer. PLoS One 2006, 1:e98.

59. Munster PN, Marchion D, Thomas S, Egorin M, Minton S, Springett G, Lee $J H$, Simon G, Chiappori A, Sullivan D, Daud A: Phase I trial of vorinostat and doxorubicin in solid tumours: histone deacetylase 2 expression as a predictive marker. Br J Cancer 2009, 101:1044-1050.

60. Ramaswamy B, Fiskus W, Cohen B, Pellegrino C, Hershman DL, Chuang E, Luu T, Somlo G, Goetz M, Swaby R, Shapiro CL, Stearns V, Christos P, Espinoza-Delgado I, Bhalla K, Sparano JA: Phase I-II study of vorinostat plus paclitaxel and bevacizumab in metastatic breast cancer: evidence for vorinostat-induced tubulin acetylation and Hsp90 inhibition in vivo. Breast Cancer Res Treat 2012, 132:1063-1072.

61. Matei D, Fang F, Shen C, Schilder J, Arnold A, Zeng Y, Berry WA, Huang T, Nephew KP: Epigenetic resensitization to platinum in ovarian cancer. Cancer Res 2012, 72:2197-2205.

62. Fu S, Hu W, Iyer R, Kavanagh JJ, Coleman RL, Levenback CF, Sood AK, Wolf JK, Gershenson DM, Markman M, Hennessy BT, Kurzrock R, Bast RC Jr: Phase 1b-2a study to reverse platinum resistance through use of a hypomethylating agent, azacitidine, in patients with platinum-resistant or platinum-refractory epithelial ovarian cancer. Cancer 2011, 117:1661-1669.

63. van Kruchten $M$, de Vries EG, Brown M, de Vries EF, Glaudemans AW, Dierckx RA, Schröder CP, Hospers GA: PET imaging of oestrogen receptors in patients with breast cancer. Lancet Oncol 2013, 14:e465-e475.

64. Yu Y, Zeng P, Xiong J, Liu Z, Berger SL, Merlino G: Epigenetic drugs can stimulate metastasis through enhanced expression of the pro-metastatic Ezrin gene. PloS One 2010, 5:e12710.

65. Hauswald S, Duque-Afonso J, Wagner MM, Schertl FM, Lubbert M, Peschel C, Keller U, Licht T: Histone deacetylase inhibitors induce a very broad, pleiotropic anticancer drug resistance phenotype in acute myeloid leukemia cells by modulation of multiple $A B C$ transporter genes. Clin Cancer Res 2009, 15:3705-3715.

66. Uil TG, Haisma HJ, Rots MG: Therapeutic modulation of endogenous gene function by agents with designed DNA-sequence specificities. Nucleic Acids Res 2003, 31:6064-6078.

67. Gaj T, Gersbach CA, Barbas CF 3rd: ZFN, TALEN, and CRISPR/Cas-based methods for genome engineering. Trends Biotechnol 2013, 31:397-405.

68. Sander JD, Joung JK: CRISPR-Cas systems for editing, regulating and targeting genomes. Nat Biotechnol 2014, 32:347-355.

69. Pandian GN, Ohtsuki A, Bando T, Sato S, Hashiya K, Sugiyama H: Development of programmable small DNA-binding molecules with epigenetic activity for induction of core pluripotency genes. Bioorg Med Chem 2012, 20:2656-2660.

70. Snowden AW, Gregory PD, Case CC, Pabo CO: Gene-specific targeting of $\mathrm{H} 3 \mathrm{~K} 9$ methylation is sufficient for initiating repression in vivo. Curr Biol 2002, 12:2159-2166.

71. Li F, Papworth M, Minczuk M, Rohde C, Zhang Y, Ragozin S, Jeltsch A: Chimeric DNA methyltransferases target DNA methylation to specific DNA sequences and repress expression of target genes. Nucleic Acids Res 2007, 35:100-112.

72. Kwon SH, Workman JL: The heterochromatin protein 1 (HP1) family: put away a bias toward HP1. Mol Cells 2008, 26:217-227.

73. Epsztejn-Litman S, Feldman N, Abu-Remaileh M, Shufaro Y, Gerson A, Ueda J, Deplus R, Fuks F, Shinkai Y, Cedar H, Bergman Y: De novo DNA methylation promoted by G9a prevents reprogramming of embryonically silenced genes. Nat Struct Mol Biol 2008, 15:1176-1183.

74. Hathaway NA, Bell O, Hodges C, Miller EL, Neel DS, Crabtree GR: Dynamics and memory of heterochromatin in living cells. Cell 2012, 149:1447-1460.

75. Rivenbark AG, Stolzenburg S, Beltran AS, Yuan X, Rots MG, Strahl BD, Blancafort P: Epigenetic reprogramming of cancer cells via targeted DNA methylation. Epigenetics 2012, 7:350-360.

76. Siddique AN, Nunna S, Rajavelu A, Zhang Y, Jurkowska RZ, Reinhardt R, Rots MG, Ragozin S, Jurkowski TP, Jeltsch A: Targeted methylation and gene silencing of VEGF-A in human cells by using a designed Dnmt3a-Dnmt3L single-chain fusion protein with increased DNA methylation activity. J Mol Biol 2013, 425:479-491. 
77. Nunna S, Reinhardt R, Ragozin S, Jeltsch A: Targeted methylation of the epithelial cell adhesion molecule (EPCAM) promoter to silence its expression in ovarian cancer cells. PLoS One 2014, 9:e87703.

78. Chen H, Kazemier HG, de Groote ML, Ruiters MHJ, Xu GL, Rots MG: Induced DNA demethylation by targeting Ten-Eleven Translocation 2 (TET2) to the human ICAM-1 promoter. Nucleic Acids Res 2014, 42:1563-1574.

79. Falahi F, Huisman C, Kazemier HG, der Vlies Pieter V, Kok K, Hospers GA, Rots MG: Towards sustained silencing of Her2/neu in cancer by epigenetic editing. Mol Cancer Res 2013, 11:1029-1039.

80. Mendenhall EM, Williamson KE, Reyon D, Zou JY, Ram O, Joung JK Bernstein BE: Locus-specific editing of histone modifications at endogenous enhancers. Nat Biotechnol 2013, 31:1133-1136.

81. Konermann S, Brigham MD, Trevino AE, Hsu PD, Heidenreich M, Cong L, Platt RJ, Scott DA, Church GM, Zhang F: Optical control of mammalian endogenous transcription and epigenetic states. Nature 2013, 500:472-476.

82. Maeder ML, Angstman JF, Richardson ME, Linder SJ, Cascio VM, Tsai SQ, Ho QH, Sander JD, Reyon D, Bernstein BE, Costello JF, Wilkinson MF, Joung JK: Targeted DNA demethylation and activation of endogenous genes using programmable TALE-TET1 fusion proteins. Nat Biotechnol 2013, 31:1137-1142.

83. Gregory DJ, Zhang Y, Kobzik L, Fedulov AV: Specific transcriptional enhancement of inducible nitric oxide synthase by targeted promoter demethylation. Epigenetics 2013, 8:1205-1212.

84. Rusk N: CRISPRs and epigenome editing. Nat Methods 2014, 11:28.

doi:10.1186/s13058-014-0412-z

Cite this article as: Falahi et al:: Current and upcoming approaches to exploit the reversibility of epigenetic mutations in breast cancer. Breast Cancer Research 2014 16:412. 